\title{
Introduction-Education's hidden crisis: An overview of the 2011 Education for All Global Monitoring Report
}

\author{
Pauline Rose
}

Published online: 6 May 2011

(C) UNESCO IBE 2011

This special issue of Prospects highlights the devastating effects of armed conflict on education. The 2011 Education for All Global Monitoring Report (GMR) identifies armed conflict as one of the most serious obstacles to progress towards the Education for All (EFA) goals. It is creating a "hidden crisis" that is reinforcing poverty, undermining economic growth, and holding back the progress of nations (UNESCO 2011). The relationship between armed conflict and education is two-way. Armed conflict is both having a devastating impact on education, and schools are too often used to transmit intolerance, prejudice, and social injustice in ways that reinforce perceived grievances and contribute to violence.

Drawing on selected background papers prepared for the GMR, this special issue presents evidence of this two-way relationship. It identifies how NGOs and international aid agencies can support education in conflict-affected countries, while highlighting the challenging circumstances in which they frequently operate. Based on the experiences of countries that have started to make a transition from conflict to peace, these articles also show that, with the commitment of national governments and aid donors, rapid education reconstruction is feasible.

This introductory article provides a synopsis of the 2011 GMR. It highlights four failures of international cooperation - in protection, provision, reconstruction, and peacebuilding - that are creating the hidden crisis. It sets out the Report's recommendations for addressing each of the four failures. It also highlights the contributions of each of the articles included in this special issue to these debates. ${ }^{1}$

\footnotetext{
1 The articles in this special issue are based on selected background papers for the 2011 GMR; all 49 papers are available at http://www.unesco.org/new/en/education/themes/leading-the-international-agenda/ efareport/background-papers/2011/. The articles and background papers reflect the views of the authors, not of the Global Monitoring Report.
}

P. Rose $(\bowtie)$

EFA Global Monitoring Report Team, UNESCO, 7, Place de Fontenoy, 75352 Paris 07 SP, France e-mail: p.rose@unesco.org 


\section{Overview of the "hidden crisis: Armed conflict and education"2}

When governments adopted the Dakar Framework for Action in 2000, they identified conflict as "a major barrier towards attaining Education for All". Evidence presented in the 2011 GMR suggests that the height of the barrier was underestimated and that insufficient attention has been paid to strategies for removing it over the past decade. According to the Report, armed conflict is one of the most serious bottlenecks to reaching the goals. Over $40 \%$ of the world's out-of-school children live in 30 poor countries affected by conflictamounting to 28 million children out of school.

The Report identifies that armed conflict most seriously affects the education of the poor and of girls. Using the GMR's Deprivation and Marginalization in Education dataset, it shows that, in conflict-affected parts of the Democratic Republic of the Congo, almost one half of girls face "extreme education poverty"-meaning that they have attended school for less than 2 years in total. One reason why girls do not attend school is the increased risk of encountering sexual violence on the way to school. In conflict-affected parts of the Democratic Republic of the Congo, 9,000 cases of rape were reported in 2009 alone; onethird of them involved children.

Shocking as they are, the figures on children out-of-school grossly underestimate the full impact that armed conflict has on education. Civilians, including children, are often caught in the crossfire of armed conflicts, or even deliberately targeted. Attacks on schools and teachers are increasingly common. The targeting of civilians leads to vast numbers of people being forced to flee their homes. They leave behind not only their livelihoods, but also their opportunities for education. An estimated 43 million people have been displaced mainly due to armed conflict; around $45 \%$ of them are under age 18 . At least $85 \%$ of those displaced live in poor countries, whose education systems are already over-stretched. Many are displaced within their own country, rather than fleeing across borders.

Data from UNHCR-run refugee camps indicate that only around two-thirds of children have access to primary school. Many refugees do not live in camps, but in informal settlements in urban areas. These refugees often lack the official papers that would allow them access to education and other basic services. In many contexts, they are also denied the right to work, so they cannot afford to send their children to school. UNHCR and other agencies are working together with governments in many countries to address these problems. But education is often not a main priority of these agencies, so they lack the know-how and resources to make EFA a reality for those who face some of the most extreme forms of disadvantage. Very little is known about those refugees who are living in urban areas or displaced internally; they are likely to be more numerous than refugees living in camps, and the available information indicates that these groups are among the most disadvantaged. In Chad, for example, only around $40 \%$ of internally displaced children have access to primary school.

Behind the figures in the Report are the real hopes and aspirations of people caught up in conflict. To take one example, Kenya has long experience of being host to refugees from conflicts in neighbouring Somalia, Sudan, and elsewhere. Over 250,000 Somalis are based in the Dadaab camps in the north of Kenya. As the camps have been established for up to 20 years, many children have only experienced life there. Others have fled the ravages of war in Somalia more recently. Despite the daily challenges facing those who live in the camps, and the scars of war they carry with them, they show a remarkable commitment to

\footnotetext{
${ }^{2}$ Unless otherwise indicated, evidence reported in this section draws on the 2011 GMR and is based on research and analysis undertaken by the GMR team (UNESCO 2011).
} 
education. As many in the camps comment: "education is the only thing we can take home".

As the Report documents, the hopes and aspirations for education of those caught up in conflict are not being met by international agencies, which often see education in these situations as a luxury rather than a necessity. The skewed priorities of national governments and aid donors are reflected in their spending patterns. The 2011 GMR identifies 21 poor countries that spend more on their military than on primary schooling. If these countries were to reallocate just $10 \%$ of their military spending to education, 9.5 million more children could have the opportunity to go to school.

Skewed priorities are also evident in the spending patterns of aid donors. The Report identifies that just 6 days of military spending by some of the world's richest countries would be sufficient to close the $\$ 16$ billion financing gap needed to achieve EFA. Reallocating less than 1 week's military spending of rich countries to basic education could put all out-of-school children into school. Even though many aid donors are beginning to recognize the importance of supporting conflict-affected countries, the motivations for their engagement often reflect concerns for national security rather than for development. The amount of aid to education has increased substantially in Afghanistan since 9/11, while it has stagnated or even declined in sub-Saharan African countries such as the Central African Republic, Chad, Côte d'Ivoire, and the Democratic Republic of the Congo. In 2007-2008, the amount of aid to basic education per school-aged child in Afghanistan was almost seven times that in the Democratic Republic of the Congo (US \$27 versus just US \$4).

The lack of a concerted effort by the international community is creating a hidden crisis in education. This must change-to ensure not only that international goals are met, but also that opportunities for improving the lives of entire generations of young people are not lost. Not only does this crisis represent a broken promise by the world's leaders to today's children and young people. It can also be dangerous. In the camps in Dadaab, Northern Kenya, schoolboys repeatedly mentioned that some of their peers, unable to continue to secondary school or get a job, intended to return to Somalia to join the militia. As documented in the 2011 GMR, in many countries limited education opportunities, or the "wrong type" of education, are fanning the flames of conflict.

The Report identifies four failures in international cooperation that are creating this hidden crisis. For each of these failures there are solutions.

First are failures of protection. The United Nations has an extensive system for monitoring human rights violations, but violations continue to go unpunished. It is estimated that over 2 million children were killed in conflict and 6 million disabled in the decade to 2008. Around 300,000 children are being exploited as soldiers, placed on the front line by warring parties. Targeted attacks on schools, teachers, and aid workers are increasingly common. According to data published by the Ministry of Education in Afghanistan, at least 613 attacks on schools were recorded in 2009, up from 347 in 2008. Violations of human rights are also reflected in the increasing number of attacks on aid workers, as Harmer, Stoddard, and DiDomenico highlight in this issue. In 2008 and 2009, almost 550 aid workers were victims of major incidents of violence; 226 of them were killed. This represents a threefold increase in the number of reported attacks compared with 2001-2002. Attacks are increasingly focused on extremely high-risk conflict environments. Between 2006 and 2009, Afghanistan accounted for 28\% of all major armed attacks against aid workers (Harmer, Stoddard, and DiDomenico, this issue).

Nowhere are failures of protection more evident than in the case of rape and sexual violence, including that against children. Sexual violence has been widely used as a tactic 
of war in many countries-including Chad, the Democratic Republic of the Congo, Liberia, Rwanda, and Sierra Leone.

More rigorous application of international law can make a difference, combined with strengthened monitoring and "naming and shaming" of those who commit such crimes. The GMR proposes that UNESCO be mandated to oversee a more comprehensive reporting system of attacks on school through a "Violence Against Education Monitoring Group". It also calls for the creation of an International Commission on Rape and Sexual Violence backed by the International Criminal Court.

Second are failures of provision. Today's conflicts often continue for many years; in the world's poorest countries, they last for 12 years on average. Yet the international community responds to conflict situations as if they were short-term emergencies. And education is not viewed as a priority in these situations. Education is the most under-funded sector in humanitarian responses-receiving just $2 \%$ of aid, with education needs going largely unmet. In 2009, only around one-third of the amount requested for education in humanitarian situations was made available.

Funding shortfalls, and the short-term planning cycles of international humanitarian agencies, mean that children are denied an opportunity for education, and that teachers cannot be paid. Despite the huge problems facing displaced people in the Democratic Republic of the Congo and Chad, appeals for education funding are largely unmet: in 2009, less than one-fifth of the funds requested for education were made available. Dolan and Ndaruhutse, in this issue, provide evidence from Save the Children's programmes in conflict-affected countries to highlight the substantial contributions the NGO has made to education, as well as the challenges it has faced. For example, in the Democratic Republic of the Congo, because insufficient funds became available through appeals, Save the Children had to seek funding from a variety of sources. Between 2005 and 2009, it received funding from 38 individual grants, 30 of them for 12 months or less. This means a considerable amount of staff time spent preparing grant applications, time that could be better spent delivering services. Failure to secure a grant can also have severe consequences. In one instance in the Democratic Republic of the Congo, cutbacks in humanitarian funding led to threats of a school being closed, and thus to children losing their opportunity for education.

The international community must show the same resolve in maintaining education for populations affected by conflict as these populations show themselves. The 2011 GMR calls for pooled funding of humanitarian aid to be scaled up and be used to top up shortfalls in education funding. These funds must also allow for flexible, multi-year support in situations of protracted conflict.

Third are the failures of reconstruction. When peace agreements are signed, they open a window of opportunity to lay the foundations for sustainable peace. Rebuilding education systems is a cornerstone of these foundations. Classrooms being built and children going to school safely are visible signs that a government is committed to showing its citizens that things have changed. The abolition of school fees also sends signals that post-conflict governments are responding to citizen demands. Social protection programmes can further alleviate the costs of schooling that can be prohibitive for those whose livelihoods are adversely affected by conflict. However, as Holmes shows in this issue, social protection programmes in conflict-affected countries have not been widely implemented, and often do not include education as a key objective.

Whalan, in this issue, draws on the experience in Solomon Islands to show what is possible when aid donors commit to post-conflict reconstruction. The conflict from 1998 to 2003 had a devastating effect on the country's education system. Many schools were 
closed as teachers and students fled the violence. In 1991, around $70 \%$ of children completed primary school; by 2003 , fewer than $40 \%$ of children were doing so. Aid donors intervened quickly, both to support the restoration of security and to provide resources for school construction and teacher salaries. This paved the way for broader reforms, including the abolition of school fees.

Displaced people consistently identify education as one of the highest priorities encouraging them to return home. Where they see schools being built and opportunities for their children to learn, they sense that their lives are returning to normal at last. It also provides a signal that the new government is committed to delivering tangible improvements in the quality of their lives. As Kim, Moses, Jang and Wils outline in this issue, the high priority that citizens place on education is apparent in South Sudan. After the Comprehensive Peace Agreement was signed in 2005, resulting in large numbers of displaced people returning home, the country witnessed a massive increase in demand for education. Enrolment in primary school more than doubled between 2006 and 2009. This has given rise to multiple challenges, including wide gender disparities, high levels of dropout, shortages of trained teachers, and a lack of permanent learning facilities.

Too often aid donors move in too slowly to help with reconstruction of education. Unless donors step up their commitment by providing long-term support to South Sudan, and to other countries in similar situations, there is a danger that these visible signs of change will not be realized, placing the prospects of peace at stake. Part of the solution is breaking down the humanitarian-development aid divide to ensure that countries are not caught in a grey area. The 2011 GMR calls for increased funding to the EFA Fast Track Initiative, and for reforms to ensure that its funds can be used in more flexible ways so they can reach conflict-affected countries.

Fourth are failures of peacebuilding. As the UNESCO constitution states so powerfully, "it is in the minds of men and women that the defenses of peace must be constructed". Education has an important role to play in countering social injustice. All too often, education has the opposite effect: reinforcing the intolerance, prejudice, and injustice in society more broadly. McLean Hilker, in this issue, shows the multiple ways that discrimination in education, including the use of quotas and biases within the curriculum, was potentially implicated in the genocide in Rwanda. While education provision has improved significantly following the genocide, including impressive increases in primary enrolment, concerns remain that some of the underlying problems have not been addressed. The author recommends a more rigorous assessment of the education system to ensure that education can play a more central role in building and sustaining peace in Rwanda.

More broadly, education systems are often an important factor contributing to the marginalization of particular groups in society, as Brown highlights in this issue. Where education opportunities are unequally distributed, for example, this can reinforce grievances and thus increase the probability of conflict. In southern Thailand, for example, the under-representation of Malay Muslims in the formal education sector and perceived attempts by the Thai state to disestablish the traditional Islamic school system are seen as contributing to conflict in the region. Brown argues that, while the education system is rarely directly implicated in fuelling violent conflict, "it is arguably one of the most important-and certainly challenging from a policy perspective-contextual factors for conflict likelihood".

Education can also be an important vehicle for building peaceful societies. Decisions about language of instruction, and the ways in which history and religion are taught, can help to promote a shared sense of identity. Peace education programmes also have a role to play. But not enough is being done to promote conflict-sensitive education planning. That 
is why the Report calls for scaling up of the UN Peacebuilding Commission, and giving education a more prominent position in its activities, with UNICEF and UNESCO taking a far more active role in promoting education for peace.

In conclusion, the 2011 GMR proposes that it is time for leaders of all countries, rich and poor, to act decisively to address these four failures, of protection, provision, reconstruction, and peacebuilding, in order to prevent brutality against some of the world's most vulnerable people, including its schoolchildren, and to ensure that progress is made towards the EFA goals.

\section{References}

UNESCO (2011). Education for All Global Monitoring Report. The hidden crisis: Armed conflict and education. Paris: UNESCO.

\section{Author Biography}

Pauline Rose (United Kingdom) has been senior policy analyst with the EFA Global Monitoring Report since April 2008. Before joining the Report team, she was a reader in international education at the University of Sussex, and deputy director of the Centre for International Education. She has published widely in the field of international education and development, and has been guest editor of recent issues of Compare, International Journal of Educational Development and Development in Practice. 